\title{
THE LEGITIMATION OF GLOBAL FOOTBALL BRANDS IN THE BRAZILIAN MARKETPLACE
}

\author{
José Sarkis Arakelian트 Eliane Zamith Brito, Benjamin Rosenthal \\ Fundação Getúlio Vargas - FGV, São Paulo, Brasil
}

\section{ARTICLE DETAILS}

\section{Article history:}

Received: 29 March 2019

Accepted: 29 November 2019

Available online January: 01 th 2020

\section{Double Blind Review System}

\section{Scientific Editor}

Ilan Avrichir

\section{Key words}

Globalization

Global brands

Market dynamics

Institutional theory

Football

\section{ABSTRACT}

\begin{abstract}
Objective: This research aims to examine the institutional changes triggered by the interplay between global and local brands to advance the understanding of the legitimation process in established marketplaces.

Method: Data was collected from blogs and sites of football specialists and in-depth interviews with professionals in the football business in Brazil. The analyses process was inductive inspired by Grounded Theory.

Main Results: The analysis provides evidence of the legitimation of global brands in the Brazilian market, and, in contrast to expectations based on previous studies, the legitimation of local brands was maintained.

Relevance/originality: Local brands maintain the legitimation and have high levels of acceptance in this social context because they are an expression of the local culture, iconic brands, and identity symbols.

Theoretical/Methodological Contributions: Understanding the dynamics of a market requires the comprehension of the legitimacy process of its institutions. The contribution of this study is to discuss the effects of the destabilization provoked by the global brands' legitimacy in local markets.
\end{abstract}

\section{Introduction}

Football is much more than a marketplace with iconic brands that inspire everybody's memories and reduce adults to tears; as a symbol of the global culture, football transcends day-to-day discussions. Football is also a large business that features myriad ramifications, club products, stadium visits, videogames, broadcasts and a host of other products and services (McDonagh, 2017). Billions of people spend time, energy and money following their football club, which situates the sport as an essential component of leisure time in contemporary societies (Dionisio, Leal and Moutinho, 2008).

Since the early 1990s, football has undergone substantial changes worldwide that have significantly impacted its stakeholders (Giulianotti, 2002) in many societies in all continents. As 'the' global game, football has been hypercommodified and is currently undergoing a transformation process with regard to the game's political economy with a new set of social and cultural global relations leading to great economic concentration in some specific clubs and resulting in the major migration of elite players with incredible salaries and highly publicized international competitions, which has changed the relationship between supporters and clubs to brands and consumers (Giulianotti, 2012).

European clubs, such as Barcelona, Real Madrid and Manchester United, have led this revolution by assuming transnational characteristics in the consumer profile, becoming big corporations, adopting a range of business strategies and consumer-oriented practices, and emphasizing profitability over all other aspects (Walsh and Giulianotti, 2001), resulting in the global diffusion of their particular symbolism (Giulianotti, 2002). The counterpart of this phenomenon is perceived in Brazil and other Latin American traditional marketplaces, such as Argentina and Mexico, due to local clubs' loss of relevance to the national identity formation and its coexistence in preference for European global brands.

Such marketplace transformation can be explained by analyzing institutions and market practices. The market dynamics research stream refers to not only market creation but also efforts to

\footnotetext{
${ }^{1}$ Contact of the author Email: jose.arakelian@fgv.br
} 
destabilize or disrupt markets by new entrants or challengers (Humphreys, Chaney and Slimane, 2017). Markets are considered organizational fields comprising a set of institutions (Scaraboto and Fischer, 2013) with cultural, ideational, social, and symbolic meanings that are recognized and accepted to define the social reality (Ertimur and CoskunerBalli, 2015) of a given society or community. Marketing has increasingly evolved with Institutional Theory, which examines institutional processes at the industry and firm levels and focuses on interorganizational relations and how organizations are influenced and interact with the institutional environment and its pressures (Slimane, Chaney, Humphreys and Leca, 2019).

Institutional Theory considers the deepest and most resilient aspects of a social structure by analyzing the processes, practices and routines that become established as authority and guidelines for social behavior. This theory investigates how these elements are created, diffused, adopted, and adapted over time and how the distinct properties of the regulatory, normative, and cultural-cognitive elements, associated activities and resources provide stability and meaning to social life. The three pillars of legitimacy (Scott, 2008) constitute a fundamental concept in Institutional Theory since they directly influence how organizations proceed and, consequently, affect their performance and survival (Deephouse, Bundy, Tost and Suchman, 2017).

Research concerning market dynamics has significantly advanced our understanding of legitimacy. The legitimation process is transformed by consumers' discourses and practices; this process contrasts local traditions and global influences (Karababa and Ger, 2011), brand-mediated market creation (Giesler, 2012), social movements as a response to market tensions (Weijo, Martin and Arnould, 2018), and the use of megamarketing to destabilize legitimation pillars in conflicts between market actors (Humphreys, Chaney and Slimane, 2017).

However, the effect on brands' legitimation of market destabilization process triggered by institutional changes due to the interplay between global and local brands is limited. The aim of the study is to advance the understanding of the legitimation process in stabilized marketplaces in which global and local brands struggle and coexist. For this purpose, the Brazilian football marketplace was analyzed. We consider Brazilian and European clubs local and global brands, respectively. These clubs have gradually shaped the discourses and practices in the market.

For the development of this research, we first review the concepts of institutional theory, legitimation, and market dynamics; then, we present the methodology adopted and describe the research results, followed by the discussion section and conclusion.

\section{Theoretical Background}

An 'institution represents a social order or pattern that reaches a certain state or property' (Jepperson, 1991) and directs how social choices are shaped and mediated; institutions establish the "rules of the game" from economic or political norms to everyday social interactions (DiMaggio and Powell, 1991) and provide stability and meaning to social life (Scott, 2008). Institutions are durable, multifaceted structures built on symbolic elements, social activities, and material resources and can be understood through their regulatory, normative, and cultural-cognitive elements (Scott, 2008). These elements form the basis of the institution's legitimacy but act independently (Scott, 2008).

As Meyer and Rowan (1977) noted, legitimacy forges formal organization coordination and control structures independently of the technical demands of the work activity, since norms are not simply general values and 'exist in much more specific and powerful ways in the rules, understandings, and meanings attached to social structures.' To comprehend this statement, we must understand the legitimacy concept and its scope. Suchman (1995) defined legitimacy as 'a generalized perception or assumption that the actions of an entity are desirable, proper, or appropriate within some socially constructed system of norms, values, beliefs, and definitions'. The author further identified the following three types of organizational legitimacy based on the taken-forgranted cultural account concept: pragmatic legitimacy reflects the capacity of an organization to achieve practical outcomes in its environment, moral legitimacy reflects a positive normative evaluation of an organization and its activities and culturalcognitive legitimacy reflects the acceptance of organizations as necessary or inevitable.

Organizations must adapt to changes in their environment over time to maintain their adequacy 
and legitimacy (Deephouse, Bundy, Tost and Suchman, 2017). Becoming inadequate involves a process of delegitimation (Deephouse and Suchman, 2013). However, the more legitimate an organization becomes, the greater the propagation of its specific organizational characteristics through interaction, which increases similarities among companies (Thornton and Ocasio, 2008). This process forcing units of a population to resemble each other is called isomorphism (DiMaggio and Powell, 1983). Therefore, once institutionalized, social knowledge exists as a part of reality (Zucker, 1977) and is suitable for transmission. Institutionalization is driven by cognitive processes that lead to taken-for-granted understandings and behaviors (Thornton, Ocasio and Lounsbury, 2012). However, the cognitive process is not detached from the normative one; Humphreys and Latour (2013) discuss the interconnectedness between the cultural-cognitive and normative levels of institutionalization.

Humphreys (2010) significantly advanced the literature concerning market legitimacy. This empirical study analyses the legitimation process of casinos in Las Vegas/USA. The author reveals the strategies adopted by casinos to win the cooperation of multiple stakeholders and how media discourses evolved. This study is important for our understanding of how markets or innovations are created and sustained in a complex social and political context. The fundamental importance of regulatory structures with rules and regulations established by governments beyond normative structures and the diffusion of vast communication build the connections necessary for the adoption and social acceptance of this market in an evident process of cultural-cognitive legitimation.

Castellano and Ivanova (2017) describe the process by which Bulgarian small wine producers gain legitimacy in a market in transition under the influence of global markets and highlighted the different legitimacy pillars involved in the process. Larger organizations established on a global level use global signals of legitimacy to shape and manipulate the 'new' local environment, directly influencing regulatory legitimacy to shape the institutional context in an 'outside-in' legitimacy process. Since normative and particularly cultural-cognitive legitimacy are based on shared long-established meanings, these signals tend to be used as the anchor points of legitimacy by local firms. Furthermore, the authors highlighted that when expanding abroad, local firms tend to reinforce their roots using 'insideout' legitimacy signals to overcome their liability of origin.

Hakala, Nummelin and Kohtamäki (2017) analyze on-line brand communities and advance our understanding of the elements and practices that influence legitimization. According to these authors, legitimacy is built by combining the perceptionjudgement action cycles taking places within the community context in multiple levels of observation, including the macro-societal level, which influences judgements in the broader discourse. In the mesolevel or organizational context, discourses are produced and interpreted. Finally, at the micro-level, which represents the community and individual context, the everyday praxis occurs. While legitimation is shaped by brand community cultural codes, perceptions, judgements, and people's actions communicate within the community and shape these cultural codes.

Despite the advances in legitimation theory, a clear understanding of the interplay between local and global brands coexisting and how legitimacy is affected is lacking. Therefore, this study seeks to investigate the dynamics of this joint existence by analyzing how global brands articulate to build their legitimization and influence the narratives and consumption practices in a stabilized market, where local brands seek to protect their status quo and maintain their relevance. This interaction produces effects on global and local brands' legitimation.

\section{Methodology}

To properly understand the context and attain the research goal, we collected data from multiple source types as explained in the following paragraphs.

First, from March 2016 to July 2019, we separated information obtained from main national media sources concerning the subject. We started following the sports sections of major Brazilian newspapers and news sites, which served as the initial main sources. In addition to these portals, as we became more familiar with the specific theme, we observed that some sports journalists mainly focus on the sports culture and market, and thus, we followed their blogs (Table 1).

By considering these interactions and using a snowball process, we started to follow many other sports media accounts on social media (Twitter) that interact and express opinions regarding the football 
market, including sports journalists, international football media, football club managers, and industry stakeholders. During the study, we separated and analyzed 592 links that presented news, studies, and opinions, resulting in 1,595 pages containing 319,804 words.

Table 1 - Sites and blogs followed

\begin{tabular}{|l|l|l|l|}
\hline Name & Type & Where & Characteristics \\
\hline Folha de São Paulo & www & folha.uol.com.br/esporte/ & Online newspaper \\
\hline O Estado de SP & www & https://esportes.estadao.com.br/ & Online newspaper \\
\hline Lance! & www & lance.com.br & Online sports newspaper \\
\hline UOL & www & uol.com.br/esporte & Online news \\
\hline Globo.com & www & globoesporte.globo.com & Online news \\
\hline ESPN & www & espn.com.br & Online news \\
\hline PLACAR & www & veja.abril.com.br/placar/ & Online sports magazine \\
\hline Máquina do Esporte & www & maquinadoesporte.uol.com.br & Online sports industry news \\
\hline MKT Esportivo & Blog & mktesportivo.com & Online sports industry news \\
\hline Trivela & Blog & trivela.com.br/ & Online football industry news \\
\hline Mauro Cezar Pereira & Blog & blogdomaurocezar.blogosfera.uol.com.br/ & Sports journalist \\
\hline Juca Kfouri & Blog & blogdojuca.uol.com.br/ & Sports journalist \\
\hline Erich Betting & Blog & negociosdoesporte.blogosfera.uol.com.br & Business sports journalist \\
\hline Rodrigo Capelo & Blog & globoesporte.globo.com/blogs/blog-do-rodrigo- & Business sports journalist \\
& capelo/ & \\
\hline Rodrigo Mattos & Blog & rodrigomattos.blogosfera.uol.com.br & Business sports journalist \\
\hline Amir Somoggi & Blog & Blogs.lance.com.br/Somoggi & Business sports journalist \\
\hline
\end{tabular}

Another data collection strategy consisted of indepth interviews, which were conducted to deepen our understanding of the market and organizational field studied. The data were obtained through 16 interviews with experts, whose selection was based on the considered relevance of their role in the marketplace (Table 2). The interviews lasted between 58 and 132 minutes for a total of 1140 minutes, generating 290 pages of transcribed text.

The interviews began with a grand tour question (McCracken, 1988), and each interviewee was asked about his/her professional start in the football market, followed by his/her opinion regarding the current market stage in Brazil in a poststructuralist interview focusing on structures and practices (Fischer, Castilhos and Fonseca, 2014). Relevant questions queried each professional's opinion regarding the structure of the national market, perceived maturity of the industry, how he/she understands the presence of European clubs in the national market, consumer behavior, concerns related to content generated by various media and the management of Brazilian and European clubs.

Table 2 - Marketplace professionals interviewed

\begin{tabular}{|l|l|l|c|}
\hline & Professional role & Entity & Interview \\
\hline P1 & Marketing Executive Director & Media Group - TV & $03 / 17 / 2016$ \\
\hline P2 & Former Marketing Director & Brazilian 1st Division Club & $05 / 24 / 2016$ \\
\hline P3 & Business Sport Journalist & Media Group - Internet and Newspaper & $06 / 03 / 2016$ \\
\hline P4 & Sport Journalist & Media Group - Internet and TV & $07 / 05 / 2016$ \\
\hline P5 & Business Director & Sponsorship Management Company & $07 / 09 / 2016$ \\
\hline P6 & Business Sport Journalist & Media Group - Internet and TV & $09 / 02 / 2016$ \\
\hline P7 & Former Marketing Director & Brazilian 1st Division Club & $09 / 08 / 2016$ \\
\hline P8 & Latam Brand Manager & Videogame Producer & $10 / 27 / 2016$ \\
\hline P9 & Former Marketing Director & Portuguese 1st Division Club & $10 / 05 / 2016$ \\
\hline P10 & New Business Director & Brazilian 1st Division Club & $01 / 19 / 2017$ \\
\hline P11 & Credit Director & Brazilian Bank & $02 / 15 / 2017$ \\
\hline P12 & Former Marketing Director & Brazilian 1st Division Club & $02 / 16 / 2017$ \\
\hline P13 & Sport Journalist & Media Group - Internet and TV & $03 / 10 / 2017$ \\
\hline P14 & Former Marketing Director & Brazilian 1st Division Club & $03 / 15 / 2017$ \\
\hline P15 & Former Director/President Club Candidate & Brazilian 1st Division Club & $03 / 06 / 2018$ \\
\hline P16 & Executive Director & International Market research Company & $08 / 18 / 2018$ \\
\hline
\end{tabular}


Data analysis was informed by an inductive logic, with codes and categories evolving progressively throughout the data collection (Miles, Huberman and Saldaña, 2013), in a process inspired by Grounded Theory (Strauss and Corbin, 2008). Axial coding was performed in order to understand the relationship between codes and categories (Miles and Huberman, 1994) and major themes (Spiggle, 1994), specifically, the interplay between consumer identity and entertainment, and the commodification resulting from the market structure and management practices.

In this last stage of the analysis, data was combined aiming to understand the practices and strategies of the clubs and the outputs of these strategies. The codes, categories and themes were organized in a visual map containing human and nonhuman actors (e.g., idols, club managers, organizational structure, local brands, international brands, athlete brands, consumers, families, and friends), activities (e.g., sponsorship, TV viewership, videogame use, news consumption, entertainment, content generation, club politics, compliance, governance), objects (e.g., stadiums, violence, ), and also the consequences or outcomes of some activities (e.g., elitism, engagement, passion, identity, financial equilibrium, and deals). This map was used as a network of meanings that facilitated the data analysis, always with the research objective in mind, in order to generate theory. Consensus between the authors was reached at the theoretical level - at the emergent themes level (Spiggle, 1994).

\section{Results}

This section describes the interplay between global and local brands and the elements that maintain their legitimacy in the Brazilian football market. Passion for football is an element of the individual identity in the Brazilian market, which is transmitted by family links, from parents to their child. Culturally is expected that each individual has unconditional love for a local football brand. This cultural-cognitive element is not well cultivated by local football brands, which take for granted the Brazilian fan support. Management practices of football clubs in the Brazilian market associated with political and economic restraints limit the development of the local brands and help to diminish the relevance of local brands businesses.
On the other hand, global brands have developed throughout time a strong market position. These brands concentrate the best football players in the world; they have mastered the global broadcasting business; they are the preferred option for videogame players that want to play with the most recent football idols. These elements reinforce mutually and create the quasi-supremacy of global brands in the world.

So, global brands compete with local brands for individuals' attention, love, and money; global and local brands have different elements that maintain their legitimacy.

\section{Interplay Between Identity and Entertainment}

In any Brazilian social circle, players and championships are the subjects of intense and endless discussions. Football is 'intrinsic to the construction of social identities and the enlivening of public life' (Giulianotti, 2012). Interviewee 3 affirmed that "you may not even like football, but you don't understand Brazil if you do not look at the country with football inside it because this country has characteristics that tie you indelibly to football". The urban landscape and football reveal many processual identity dynamics since 'there is an identity around selection that is independent of the degree of individual adhesion of this or that subject because the possession is collective, shared' (Toledo, 2010). The belonging feeling can be perceived in the following testimony:

The most significant marketing idea we had was the campaign 'Popular Republic'. We like Brazil, and we live here, but if our club faces the Brazilian National Team, you'll see where the crowd would be! People want to see the club fight racism, campaign for blood donation, fight urban violence [...]. These kinds of things give pride, self-esteem to supporters, to us, and then, you get into a crazy world! (P14)

However, while football is a global game, it can be understood as global entertainment (Giulianotti, 2012). In Brazil, the panorama has changed decades ago, and the change is visibly captured in the multiplication of sportwear, indicating the support of European clubs by young people; however, 'have players, fans or identities changed in the dynamics of global cities? Certainly, all of them at the same time' (Toledo, 2010) worldwide. 
The importance perceived in the idea of transmitting the 'club's passion' to children indicates the football club's importance in the identity formation process. In the post "Letter to a young fan", Journalist Fabio Seixas registered the memories of the day he took his daughter to a stadium for the first time. The author described the symbolic set of values and meanings that was received from his father and transmitted to his daughter, resulting in the unity of feelings between generations.

Julia, I decided to write you this letter because although we shared that tight hug at the end of the match and you said to me that "it was the most special day of your life", you may not remember all the details in the future. I remember when my father took me to my first match. It was Santos vs. Ponte Preta in Pacaembu Stadium. I still have the entrance ticket with me, but I have no idea about the score. I only remember my amusement when my father showed me the "guys pissing ladder" and all the swearing I learned in those bleachers. That day shaped me. That experience began to make me who I am today... All of this, all the importance of my first match hit me this morning, and I cried like a child; I was about to call your grandfather and barely managed to talk to him. I certainly could not put into words what I was feeling. I could not thank him for what he did to me that day [...]. The fact is that there will be many other goals in your life, and your father will be by your side to celebrate. I could not help but smile when the loudspeakers announced the audience of today's final: 73,531. This "1" was the most special fan I've ever seen. Love you! Daddy. (Fabio Seixas, 2013)

In Brazil, occasions during which passion is expressed accumulate, such as the travel of tens of thousands of Brazilian Corinthians fans to Japan in 2012 for the Fédération Internationale de Football Association (FIFA) World Club tournament.

Some years ago, 30,000 Corinthians supporters travelled from Brazil to Japan! Guys spent money they didn't have; US\$10,000, US\$ 20,000 each. There's no more significant demonstration of passion for a club. What did the club managers do after this to keep this feeling alive? Nothing, absolutely nothing [...] I'm not even criticizing the club. I'm criticizing the market structure in Brazil, which is not prepared and is not professional to deal with things like this (P2).

This excerpt shows the explicit tension in the relationship between supporters and club managers that has gradually developed over time. In February
2017, a survey conducted in the city of São Paulo (Datafolha, 2017) showed that only $24 \%$ of the population surveyed did not have a preferred club, demonstrating that most of the Brazilian population takes "having a preferred football club" for granted. However, in the same survey, $60 \%$ of those who claimed to have a preferred club could not name at least three players from their current squad. This result indicates some distancing. This situation is confirmed by research conducted by SPC Brazil explaining the habits, attitudes and consumption behaviors of Brazilians, which showed that $53.1 \%$ of Brazilians (60.6\% of men) follow news about clubs daily and that $73.3 \%$ of the sample watch games at least once a week, although only $17.5 \%$ are in the habit of visiting stadiums (SPC Brazil, 2016).

These data highlight a large market that has not been adequately exploited by local brands. Interviewee 1, a TV executive director, clarifies this issue by stating that "the greatest competition today is for the time of the consumer, who has less and less time to do everything he/she wants to do". Interviewee 3 shares the following view:

It's necessary to understand the product as the national championship instead of seeing only his club in the market. All clubs together make up a great product [...]. They must definitively understand that they compete with cinema, theatre, the beach because they are also entertainment options and are the options on which consumers will spend their income and their time (P3).

Interviewee 11 completes the idea by stating that "we can understand the fan who wants his/her team to win everything and all others being relegated. It is typical and natural, but managers have to focus on the spectacle, on the industry, not "me against the world". The football stadium is one of those "rare spaces where collective emotions are unleashed, where such a dramatic spectacle in which the narrative develops, and the watching public who can - or believe they can - influence, and even change, the denouement' (Bromberger, 1995). However, the practice of visiting the stadium, which may be the element necessary to maintain passion for a club and, consequently, make football an entertainment priority, has been neglected by the management of clubs, which has not attempted to encourage traditional consumers and youngsters to visit the games, which may trigger signals beyond the current reduction in revenue. 
If in 15 to 20 years the son of the guy who nowadays has stopped going to the stadium prefers to watch YouTube or play videogames, what can be done? TV will no longer pay because the audience will be low and falling. Today, the audience has not been renewed, and nobody noticed this. Nobody talks! (P4).

How does a person engage in football? At the stadium! People have to go to the stadium, have to watch, have to feel the cheering for his club. That's the way things work in this business. But, people have been discouraged from going there, living it in person, either by the price of the tickets, which are so expensive, or by the lack of security. We're indirectly stimulated to consume content that comes from abroad digitally (P3).

The focus on engaging consumers, which is natural in other industries, does not seem to be explored in essence in the Brazilian football industry.

The issue of the digital revolution impacts everything. Sponsorship, supporters and all the relationship with the media. Society and, of course, the clubs still do not understand the impacts. The consumers' protagonism has changed the whole ecosystem (P16).

And you cannot talk about business without being tied to the guy who pays the bill. Because when we are no longer so essential to the consumer, we have to review the business as a whole. Because if it is less interesting to the consumer, then so it will be to the sponsor and, of course, to the media groups, and then, the whole chain goes down (P1).

\section{Commodification by the Market Structure and Management}

The Brazilian Football Confederation (CBF), which brings together various state federations to organize championships and the sport as a whole, sustains the football market structure in Brazil. Many interviewees highlighted this structure as a major limiting factor in the Brazilian marketplace. CBF managers do not dedicate sufficient effort to local clubs as exemplified by interviewee 13 , who affirmed that the confederation deliberately had a strategy to reduce the importance of national clubs to the detriment of the Brazilian national team.

A former Brazilian FIFA president realized the opportunity to make football the number one global entertainment industry. [...] He did not adjust the local calendar to the world calendar; so, Brazilian clubs became unable to tour, and this situation stimulated the exportation of players. [...]. In any sports shop in the world, you can always find the Brazilian yellow jersey but never that of any Brazilian club because no one outside of Brazil knows any of them (P13).

Focusing on the local market, the same structure that permits the business to be large limits the growth of the clubs.

There are two macro-entities, the TV media group that owns the football rights and federations/confederations that explore this big business. You can see how much the TV rights are worth, how much the TV transmission sponsorship quota is evaluated as, and the CBF surplus with sponsorships, national team friendly games and such, but the clubs do not participate in that. Perhaps the incompetence and amateurism of the clubs allow both entities to enjoy this so much, and maybe they explain a little why this macrostructure never changes and why the club is always limited because the better you do your work in the club, if the environment is not strictly speaking professional, you will still be limited to a ceiling (P10).

In Brazil, clubs have an associative nature, and their management is generally not carried by professionals. There is a legal opportunity for clubs to be transformed into companies, but there is no indication that doing so can be a real possibility, unless a change in the law obliges them. The demands of the football business have been disproportionate to the clubs' managerial capacity.

They are social clubs with amateur leaders who earn nothing to be there, with management terms of 2 or 3 years; so, even if they want to do it the right way and have the skills to, they would not have the time to plan and pick up their laurels. The same leader takes care of US\$ 150 million of revenue from football and the social demands of the swimming pool, the tennis court or bowling. This amateur model makes room for all kinds of politics [...]. It just cannot work (P3).

The participation of a skilled professional in the management team of clubs is uncommon, although the size of the clubs would require that type of professional to be adequately managed. This strangeness indicates the lack of cultural legitimacy (Suchman, 1995) among national clubs. The organizational field is definitively established, and isomorphism (DiMaggio and Powell, 1983) operates at all levels with similar management and actors. Interviewee 2 describes his hiring, which in his vision, occurred inappropriately at the suggestion of the son of an associate. 
I went there to talk to the president. After half an hour of talking, he told me, "Well, okay. I'm convinced," and, he hired me. Look, it was me, but the guy was wrong. It cannot be like that [...]. He was very well-intentioned, but it could not have been either. There's no governance system (P2).

The model even hinders strategic decisions by professionals who are prepared to make such decisions.

There is so much pressure and confusion that even top professionals get in the way when they take over positions at clubs. At one point in a YouTube project, we were nominated for the Best Marketing Award of the year, competing with international recognized companies. I was pleased and communicated to my elected director, who at that time was a large international bank superintendent, who asked immediately "how much would it cost to participate, and what revenue could it generate?" Dude, do you think such a guy does not know what branding is and how it works? The pressure is so great that the only concern is for the revenue to pay the salary of player " $x$ " in the following month (P11).

Professionalization is undoubtedly one significant difference between the management of football in Brazil and that in Europe. Interviewee 7, who has had a career in a European club and was most recently working in the Brazilian market, highlights the difference in the management structure.

(European clubs) have a strong, independent marketing area and understand it as a revenue generator. The president enters, the president leaves, and the marketing structure remains. There are club investments in that business vision; so, the structure is maintained. Some people even change, but the structure, the investment, remains. Here, in Brazil, there is a big political scheme. When a new president comes, he changes the whole board, which, in turn, will change the whole team; so, you lose the history, all the projects. Therefore, it's complicated, [...] it will never exit this loop (P7).

European football clubs are assuming a growing role in the world market, and in Brazil, they are in the process of gaining legitimacy; these "new to the market" clubs currently occupy the place that was previously held by Brazilian clubs. Barcelona, Real Madrid, and other clubs assume the symbols of "big teams" and the "model of how a great winner has to be" in the market and our social field.
Several factors contribute to the legitimation process of European clubs, such as brand positioning, fan access to information about the clubs and games, and game broadcasting, which are important factors in this process. Interviewee 4 emphasizes access, which did not previously exist, as follows, "Nowadays, the Europeans are followed because doing so is possible. When I was a kid, I wanted to know about European matches, but I couldn't unless I had a chance to read an imported magazine or newspaper".

Economic power is a part of the explanation of this supremacy. The 1995 Bosman Law, which established the free movement of European players among the community countries, was a fundamental factor in this process in the evaluation of many experts on the subject and as explicitly stated by Leonardo Bertozzi (2014).

The Bosman law created a free zone for athletes in Europe, generating an absurd concentration process there. The Yugoslavian Red Star had been the Champions League winner shortly before the law, but it will never be again because every year, the five, six major teams of the continent take all the star players that appear on any team in every corner of the world.

The process of economic concentration enables the best players, idols, and media figures who play a crucial role in the process of legitimation as symbols (Scott, 2008) to be concentrated in major European clubs. Regarding this idea, interviewee 1 states, "I understand international football nowadays as a very strong product because of the idols, and for sure, Brazilians like idols a lot! ". Interviewee 2 complements this perspective by stating, "Who is the great Brazilian idol today? Neymar? And, where is he? In Europe [...]. He is a Brazilian product, but a kid who likes him will buy his shirt, no matter which club he is. So, where does the money go?" The export process of our leading players and idol candidates does not cease and becomes increasingly naturalized and institutionalized (DiMaggio and Powell, 1983).

Interviewee 6 noted that the problem is not only an economic issue. He stated, "How am I going to attract a guy who can play with the top players of the world, offering him a regional championship without any appeal, playing against divisional teams in the interior of the state for four months? Certainly not". The Brazilian youth player Vinicius Jr, who was transferred from Flamengo to Real Madrid, corroborated this view. In an interview, he said that "in two months in Madrid, I evolved what would take 
a year in Brazil. The training methodology is different, getting along with the best players [...]. The difference is enormous" (Mansur, 2019). Interviewee 7 optimistically argued that the situation can be reversed as follows:

The boys today have no idols in Brazilian clubs, which is different from my generation. If you ask kids if they want a Palmeiras or Manchester jersey, the answer will be Manchester for sure! [...] It is an easily reversible process, but you need to start looking at it because in a little while, 20, 30, 40 years if you do not manage it, we can have serious problems in the Brazilian football market (P7).

An important instrument in these dynamics, especially for new generations, is the videogame. In 2015, in the US alone, this market generated revenues of US\$ 3.13 billion (Fortune, 2016), and the FIFA17 game was the best-selling console game worldwide. The importance of videogames in communication and even in legitimation is common sense. In such games, Brazilian clubs are much weaker than European clubs, and children avoid choosing them and prefer to play the European clubs, which are much more familiar to them than Brazilians clubs, reinforcing their brand preference. Interviewee 3 elaborates upon this process as follows:

European clubs start arriving in broadcasts and in videogames, on which kids spend much more time. On the PS4, boys do not play as Corinthians and play as Barcelona because they want to control Messi and Soares. These are the kids today. [...] Why should they prefer playing as a guy from Corinthians, who will move to China next year, instead of playing as Messi? See, they started to compete for attention, money, and time. Everyone is competing for the same kid. It would be hard for Brazilian clubs, even if they could do it right here in Brazil (P3).

The process of globalization and the concentration of wealth are indisputable. However, the manner in which Brazilian managers have treated this phenomenon must be contested as Interviewee 13 states the following:

I'm not naive and understand economics, finance and the globalization process, but if we had at least a minimum level of management, we would endure this influence. The Italian or Spanish boy would also be watching our championship because we could still be attractive [...] One thing is letting great players go to the best European clubs. We definitely cannot resist, but to other European or Asian clubs? (P13)

Brand internationalization in the most diverse markets is not new given that brands and their management practices can be understood as institutional forces with profound impacts on the perception of the market and the consumer as a social category playing a central role in the structure of commercial activities and economics (Askegaard, 2006).

Brazilian clubs do not explore their brand even nationally. Thus, international expansion is a distant objective. Thus, Interviewee 10 states that "the closest we are to internationalization is as the sellers of players, as an exporter of commodities, a kind of raw material". Antero Greco, a sports journalist, wrote the following in his column in the Estado de São Paulo newspaper about football globalization and its effects on the local marketplace:

European clubs have such seductive power that it seems even shameful to support local teams. [...]

[...] Sad reality! We see children, youths and even some grown men declaring their "love" for Real Madrid, Barcelona. Me, no!?! It seems that we have such a colonial complex with regards to the Europeans' power and seduction that we are even clumsy in admitting an exclusive passion for local clubs. It sounds very old-fashioned. There's just no way! (Greco, 2018).

Therefore, whether Brazilian brands will, in fact, be replaced in the long run remains questionable.

They are going to conquer our supporters? They will not! [...] Or not! The Europeans clubs are already taking the kids. You already see generations that grow up in another environment where football is already a more globalized business. So, cheering for Barcelona may be the same as cheering for Corinthians. Imagine that I live in Fortaleza. What is the difference between cheering for Barcelona or Corinthians? Both are far away from me (P6).

The identity issue resists! You must have had the experience of putting your club's shirt on your son or daughter, who understands nothing at that age, and took a happy picture! (P10).

I don't know how it will be in the future, but nowadays it's not quite that much because of the passion. The guy supports the club that it's still part of his reality, the club that his father cheers for, his grandfather... or the rival! (P4). 


\section{Discussion}

The Bosman Law in the 1990s allowed the emergence of clubs that resemble multinational teams with a senior technical level due to the possibility of hiring football idols from the most diverse nationalities. This law induced a significant change in the football global competitive landscape. Europeans clubs exposed to this market disruption, restructured their management and branding. They have adopted practices and also hired professionals from other industries; thus, these clubs began to be managed similarly to any other global brands. European national championships, which once focused on local audiences, became global.

The worldwide success of the European teams has established a new way of acting and doing business in the football; and this is what Zucker (1977) proposed, once the existence of institutionalization emerges as a fact, it is part of the directly transmitted objective reality.

The institutionalization of the use of video games as a form of entertainment and, in particular, football games, was another factor that boosted the success of European brands. Videogame players prefer the teams with the idols, as this choice increases their chances of success in the game. It is appropriate, that is, it is legitimate (Suchman, 1995) playing with world idols. This simple fact helps to normalize the supremacy of European clubs and the identification of fans with the idols and teams.

In Brazil, the football market over time has been adapting to the new circumstances; the local football market, which until the emergence of European clubs had experienced limited foreign influence, became increasingly exposed to global competitors. The renewed market actors challenged and destabilized the traditional order.

So, the regulatory pillar based on the state and regulatory authority that enforce and authorize actions with laws (Scott, 2008) changed the way European clubs were established elsewhere, but the new configuration affected the Brazilian football business. The direct effects of these changes were lack of resources by local clubs to retain their best players, which impoverished the spectacle and entertainment they provided. This circular process has led to the repositioning of the local clubs and brands in the global market.
We show the role of identity in the resistance of local brands. Individuals are expected to develop unconditional love for the local football brand that their parents are also fans (normative legitimacy), but they also feel the emotion of being a fan and part of the local club (cognitive legitimacy); the individual is subjected to a narrative which integrates the culturalcognitive and normative levels of legitimacy (Golant and Sillince 2007), and which maintain he or she attached to the local brands. Castellano and Ivanova (2016) noted that cultural-cognitive and normative legitimacy pillars are fundamental when there is a transition in a market exposed to global influence. The cultural-cognitive pillar indicates the common conceptions and social practices that are internalized and understood by all as parts of the accepted and embodied schemes; however, the normative pillar determinates what is expected or appropriate in each determinate social occasion, thereby influencing social behaviors (DiMaggio and Powell, 1991).

Consumers are exposed to ubiquitously information about the clubs, games, players, professional social media-generated content, and they have access to live broadcast of championships; all these reinforce European clubs' superiority, legitimating these brands in the marketplace. In contrast, these elements have the opposite effect on local brands in a delegitimation process (Deephouse and Suchman, 2013). Brands are exposed to multiple levels of observation, and as Hakala, Nummelin, and Kohtamäki (2017) proposed, the consumer community is not only influenced by brand management but also shapes cultural codes.

Identification with a football club is the reason for creating and evolving the market, and one cannot fully experience the excitement of football without engaging with one group (players and fans) in the stadium, disputing the football match. This involvement is what makes sense because people who do not have any connection to a club will likely not visit the stadium or watch a game on TV (Bromberger, 1995; Damo, 2006). Damo (2006) illuminated this connection as a symbolic representation, i.e., the driving force of the football spectacle, since fans identify with teams because they represent clubs. 'The teams can change from season to season, but the club remains and is protected by its traditions and mythologies'. The supporter identifies with the club and, by extension, an imagined community that has the same connection, i.e., with whom they want to be (Damo, 
2008); in this context, the choice of a club to cheer for is an absolutely important, natural but not a rational process in which the attraction 'presupposes seduction and co-optation about the neophytes by the fans already engaged to the club' (Damo, 2008).

Finally, this dynamic changed the market with the effects of globalization and the importance and value attributed to sports and entertainment. The industry becomes professional with actual demands, and to survive with relevance, adjustments in the structure and understanding of the market by local brands are necessary. The process legitimates global brands, which will be a part of the identity process of the next generations, while local brands try to adapt to the global brands business model and search for differentials, such as engagement and closeness, to remain relevant.

\section{Conclusion}

The aim of this study was to advance the understanding of how the interplay between global and local brands affects their legitimation in stabilized marketplaces. Therefore, we analyzed how market dynamics is transformed and how social knowledge became legitimized (Suchman, 1995). We show how global brands are shaping behaviors and practices and being institutionalized at the regulatory, normative and cultural-cognitive levels, and we present the local brands' reactions to this process. Humphreys (2010) highlighted the essential importance of regulatory and normative structures building the environment for social acceptance, representing a cultural-cognitive legitimation of market transformation, but there was limited research in contexts in which social acceptance to previous firms (local football brands) remains robust, and this study contributes to this understanding.

In an effective strategy, European clubs have become global brands with a highly attractive power legitimated to this audience; European clubs have begun to compete with local brands for attention and consumption, especially among the new generations, but in a different connection. The clubs compete in different championships; they do not have direct rivalry in games. Therefore, it is becoming usual for kids to cheer for a local club while also following European clubs. They do not substitute the local brand for a global brand; they become a fan of multiple brands, dividing their attention, time and, naturally, consumption and legitimate (Suchman,
1995) different brands in a different form of entertainment consumption.

Clubs exist in relation to other clubs, and the most powerful ones tend to be precisely those involved in rivalries while dualism predominates (Damo, 2006); however, to date, such rivalry was circumscribed to local markets and worldwide competitions. Further research could investigate how consumers understand this relation between brands, such as whether supporters of local clubs in fact become supporters of a European club. The use of Institutional Logics (Thornton and Ocasio, 2008) as a theoretical framework could provide insight into this dynamic. Inspired on the Giesler (2012) work, the rise of European brands can be analyzed through the lens of actor-network theory.

\section{References}

Askegaard, S. (2006). Brands as a global ideoscape. Brand culture, 91-102.

Bertozzi, L. A Lei Bosman se consolidou e mudou o futebol mundial. Disponível em http://trivela.uol.com.br/trivela-15-anos-lei-bosmanse-consolidou-e-mudou-o-cenario-na-europa-porleonardo-bertozzi/ Access in 07/14/2014.

Bromberger, C. (1995). Football as world-view and as ritual. French Cultural Studies, 6(18), 293-311.

Castellano, S., and Ivanova, O. (2017). Signaling legitimacy in global contexts: the case of small wine producers in Bulgaria. European Business Review, 29(2), 243-255.

Damo, A. S. (2006). A magia da seleção. Revista Brasileira de Ciências do Esporte, 28(1), 73-90.

Datafolha . Time de preferência e opinião sobre futebol em São Paulo. Disponível em <http://media.folha.uol.com.br/datafolha/2017/03/01/ 11f6fbe9ed8153c091e0d3d1f320753321c808c8.pdf>. Access in 04/28/2017.

Deephouse, D. L., Bundy, J., Tost, L. P., and Suchman, M. C. (2017). Organizational legitimacy: Six key questions. The SAGE handbook of organizational institutionalism, 27-54.

Deephouse, D. L., and Suchman, M. (2013). Legitimacy in organizational institutionalism. In Powell, W. W., Colyvas, J. A., Greenwood, R., Oliver, C., Sahlin, 
K., \& Suddaby, R. (2008). The Sage handbook of organizational institutionalism, 49-77.

Dionisio, P., Leal, C., and Moutinho, L. (2008). Fandom affiliation and tribal behaviour: a sports marketing application. Qualitative Market Research: An International Journal, 11(1), 17-39.

DiMaggio, P. J., and Powell, W. W. (1983). The iron cage revisited: Institutional isomorphism and collective rationality in organizational fields. American Sociological Review, 48(2), 147-160.

(1991). The new institutionalism in organizational analysis. University of Chicago Press.

Ertimur, B., and Coskuner-Balli, G. (2015). Navigating the institutional logics of markets: Implications for strategic brand management. Journal of Marketing,79(2), 40-61.

Fischer, E., Castilhos, R., and Fonseca, M. (2014). Entrevista qualitativa na pesquisa de Marketing e do consumidor: Abordagens paradigmáticas e orientações. REMark, 13(4), 67-79.

Folha de São Paulo. Maioria dos paulistanos não sabe o nome dos jogadores do seu time. Disponível em $<$ http://www1.folha.uol.com.br/esporte/2017/03/1862 592-maioria-nao-sabe-os-atletas-do-time-para-o-qualtorce.shtml>. Access in: 03/02/2017.

Fortune.com. Level up! Video Game Industry Revenues Soar in 2015.Disponível em < http://fortune.com/2016/02/16/video-game-industryrevenues-2015/>. Access in 07/15/2016.

Giesler, M. (2012). How doppelgänger brand images influence the market creation process: Longitudinal insights from the rise of botox cosmetic. Journal of Marketing, 76(6), 55-68.

Giulianotti, R. (2002). Supporters, followers, fans, and flaneurs: A taxonomy of spectator identities in football. Journal of Sport and Social Issues, 26(1), 25-46.

Giulianotti, R. (2012). Football. The Wiley. Blackwell Encyclopedia of Globalization.

Golant, B. D., and Sillince, J.A.A. (2007), The Constitution of Organizational Legitimacy: A Narrative Perspective, Organization Studies, 28 (8), 1149-67.

Greco, A. (2018). Brasil Colônia. Disponível em < http://esportes.estadao.com.br/noticias/futebol, brasil-colonia,70002410346>. Access in 07/22/2018.
Hakala, H., Niemi, L., and Kohtamäki, M. (2017). Online brand community practices and the construction of brand legitimacy. Marketing Theory, 17(4), 537-558.

Humphreys, A. (2010). Semiotic structure and the legitimation of consumption practices: The case of casino gambling. Journal of Consumer Research, 37(3), 490-510.

Humphreys, A., and Latour, K. A. (2013). Framing the game: Assessing the impact of cultural representations on consumer perceptions of legitimacy. Journal of Consumer Research, 40(4), 773-795.

Humphreys, A., Chaney, D., and Slimane, K. B. (2017). Megamarketing in contested markets: The struggle between maintaining and disrupting institutions. Thunderbird International Business Review, 59(5), 613-622.

Jepperson, R. L. (1991). Institutions, Institutional Effects, and Institutionalism. In DiMaggio, P. J., \& Powell, W. W. (Eds.). (1991). The new institutionalism in organizational analysis. University of Chicago Press.

Karababa, E., and Ger, G. (2011). Early modern Ottoman coffeehouse culture and the formation of the consumer subject. Journal of Consumer Research, 37(5), 737-760.

Mansur, C. E. Vinicius Junior: 'Em dois meses no Real Madrid, evoluí o que levaria um ano no Brasil'. Disponível em < https://extra.globo.com/esporte/vinicius-junior-emdois-meses-no-real-madrid-evolui-que-levaria-um-anono-brasil-23774435.html>. Access in 05/11/2019

McCracken, G. (1988). The long interview. Sage Publications.

McDonagh, P. (2017). Football-marketplace icon? Consumption Markets \& Culture, 1-5.

Meyer, J. W., and Rowan, B. (1977). Institutionalized organizations: Formal structure as myth and ceremony. American Journal of Sociology, 83(2), 340363.

Miles, M. B., and Huberman, A. M. (1994). Qualitative data analysis: An expanded sourcebook. Sage Publications.

Miles, M. B., Huberman, A. M., and Saldaña, J. (2013). Qualitative data analysis: A methods sourcebook. SAGE Publications. 3rd. 
Scaraboto, D., and Fischer, E. (2013). Frustrated fatshionistas: An institutional theory perspective on consumer quests for greater choice in mainstream markets. Journal of Consumer Research, 39(6), 1234-1257.

Seixas, F. Carta a uma jovem torcedora. Disponível em

https://fabioseixas.blogfolha.uol.com.br/2013/06/30/c arta-a-uma-jovem-torcedora/ Access in 14/07/2016

Scott, W. R. (2008). Institutions and organizations: Ideas, interests, and identities. Sage.

Slimane, K. B., Chaney, D., Humphreys, A., and Leca, B. (2019). Bringing institutional theory to marketing: Taking stock and future research directions. Journal of Business Research, 105 (Dec), 389-394.

SPC Brasil. (2016). Gastos com futebol desequilibram orçamento de 2 em cada 10 torcedores. Disponível em <https://www.spcbrasil.org.br/pesquisas/pesquisa/1970>. Access in 01/09/17.

Spiggle, S. (1994). Analysis and interpretation of qualitative data in consumer research. Journal of consumer research, 21(3), 491-503.

Corbin, J., and Strauss, A. (2008). Basics of Qualitative Research. (3 ${ }^{\text {rd }}$ Ed.). Sage Publications.
Suchman, M.C. (1995) 'Managing Legitimacy: Strategic and Institutional Approaches', Academy of Management Review 20(3): 571-611.

Thornton, P. H, and Ocasio, W (2008). Institutional logics. The Sage handbook of organizational institutionalism, 840p, 99-128.

Thornton, P. H., Ocasio, W., and Lounsbury, M. (2012). The institutional logics perspective: A new approach to culture, structure, and process. Oxford University Press.

Toledo, L. H. de (2010). Torcer: a metafísica do homem comum. Revista de História, (163), 175-189.

Walsh, A. J. and Giulianotti, R. (2001). This sporting mammon: A normative critique of the commodification of sport. Journal of the Philosophy of Sport, 28(1), 53-77.

Weijo, H. A., Martin, D. M., and Arnould, E. J. (2018). Consumer movements and collective creativity: The case of restaurant day. Journal of Consumer Research, 45(2), 251-274.

Zucker, L. G. (1977). The role of institutionalization in cultural persistence. American Sociological Review, 42(5), 726-743.

\section{About Authors}

José Sarkis Arakelian - Fundação Getúlio Vargas - FGV, São Paulo, (Brasil). E-mail: jose.arakelian@fgv.br Orcid id: https://orcid.org/0000-0002-1871-4218

Eliane Zamith Brito - Fundação Getúlio Vargas - FGV, São Paulo, (Brasil). E-mail: eliane.brito@fgv.br Orcid id: https://orcid.org/0000-0002-7340-1337

Benjamin Rosenthal - Fundação Getúlio Vargas - FGV, São Paulo, (Brasil). E-mail: benjamin.rosenthal@fgv.br Orcid id: https://orcid.org/0000-0001-7259-5144 


\title{
A LEGITIMAÇÃO DAS MARCAS GLOBAIS DE FUTEBOL NO MERCADO BRASILEIRO
}

\author{
José Sarkis Arakelian, Eliane Zamith Brito, Benjamin Rosenthal \\ Fundação Getúlio Vargas - FGV, São Paulo, Brasil
}

\section{DETALHES DO ARTIGO}

\section{Histórico do Artigo:}

Recebido: 31 de março de 2019

Aceito: 29 de novembro de 2019

Disponível online: 01 de jan. de 2020

Sistema de revisão "Double blind review"

Editor Científico

Ilan Avrichir

\section{Palavras-Chave}

Globalização

Marcas globais

Dinâmica de mercado

Teoria institucional

Futebol

\section{RESUMO}

Objetivo: A pesquisa tem por objetivo examinar as mudanças institucionais desencadeadas pela interação entre marcas globais e locais para avançar no entendimento do processo de legitimação de marcas em mercados existentes. Metodologia: Dados foram coletados de blogs e sites de especialistas em negócios de futebol e por entrevistas em profundidade com profissionais no mercado de futebol no Brasil. O processo de análise foi indutivo, inspirado em Grounded Theory.

Principais Resultados: A análise dos dados evidencia a legitimação de marcas globais no mercado brasileiro e, diferentemente do que sugerem estudos anteriores, a legitimação das marcas locais foi mantida.

Relevância/Originalidade: Marcas locais mantém sua legitimidade e possuem altos níveis de aceitação nesse contexto social porque são uma expressão da cultura local, marcas icônicas e símbolos de identidade.

Contribuições Teóricas/Metodológicas: Compreender a dinâmica de um mercado requer entender o processo de legitimação de suas instituições. A contribuição deste estudo é discutir os efeitos da desestabilização provocada pela conquista da legitimidade pelas marcas globais no mercado local.

\section{LA LEGITIMACIÓN DE LAS MARCAS GLOBALES DE FÚTBOL EN EL MERCADO BRASILEÑO}

José Sarkis Arakelian, Eliane Zamith Brito, Benjamin Rosenthal

Fundação Getúlio Vargas - FGV, São Paulo, Brasil

\section{HISTORIA DEL ARTÍCULO}

Historia del Artículo:

Recibido: 31 Marcha 2019

Aceptado: 29 Noviembre 2019

Disponible en línea: 01 de enero 2020

Double Blind Review System

\section{Editor Científico}

Ilan Avrichir

\section{Palabras-clave}

Globalización

Marcas globales

Dinámica del mercado

Teoría institucional

Fútbol

\section{RESUMO}

Objetivo: En este artículo, examinamos los cambios institucionales provocados por la interacción entre las marcas globales y locales para avanzar en la comprensión del proceso de legitimación de la marca en los mercados existentes.

Metodología: Este estudio utiliza datos recopilados de blogs y sitios de especialistas en fútbol y entrevistas con profesionales en el negocio del fútbol en Brasil. El proceso de análisis fue inductivo inspirado en la Grounded Theory. Resultados Principales: El análisis proporciona evidencia de la legitimación de las marcas globales en el mercado brasileño y en contraste con las expectativas basadas en estudios previos, se mantuvo la legitimación de las marcas locales. Relevancia/Originalidad: Las marcas locales conservan su legitimidad y tienen altos niveles de aceptación en este contexto social porque son una expresión de la cultura local, marcas icónicas y símbolos de identidad.

Contribuciones teóricas/metodológicas: Comprender la dinámica de un mercado requiere entender el proceso de legitimación de sus instituciones. La contribución de este estudio es discutir los efectos de la desestabilización provocada por la legitimidad de las marcas globales en el mercado local.

Cite it like this:

Arakelian, J., Brito, E., \& Rosenthal, B. (2020). The Legitimation of Global Football Brands in the Brazilian Marketplace. Internext, 15(1), 104-117. doi: http://dx.doi.org/10.18568/internext.v15i1.540 